\title{
On the Neotropical Rhabdepyris Kieffer (Hymenoptera, Bethylidae) of the subgenus Chlorepyris
}

\author{
Celso Oliveira Azevedo ${ }^{1}$
}

\begin{abstract}
Rhabdepyris longifoveatus sp.n. from southeastern Brazil and R. vesiculosus sp.n.. from Central America and northwestern South America are described and illustrated. Rhabdepyris virescens Evans, 1965, $R$. vesculus Evans, 1065, $R$. subviridis (Kieffer, 1906), R. violaceus Evans, 1965, R. septemlineatus Kieffer, 1906 and $R$. lobatifions Kieffer, 1906 had their sting and male genitalia described.

KEY WORDS. Hymenoptera, Bethylidae, Rhabdepyris (Chlorepyris), Neotropical
\end{abstract}

Rhabdepyris Kieffer, 1904 is one of the most important genus of tribe Epyrini, with about 110 species in all regions around world. It is particularly rich in the Neotropica, where there are about 50 species. EVANS (1964) placed Trichotepyris Kieffer, 1906 and Chlorepyris Kieffer, 1913 as synonymies of Rhabdepyris and Evans (1965) reorganized them as subgenera, including Rhabdepyris sensu strictus, and revised the genus for the Americas, describing 28 new species. AZEVEDo (1992a,b, 1993) studied some species from southeastern and southern Brazil.

This paper represents another one regarding Neotropical Rhabdepyris. Two new species are described and illustrated, $R$. longifoveatus sp.n. from São Paulo State, Brazil and $R$. vesiculosus sp.n. from Panama and Ecuador. Type material and additional specimens of $R$. virescens Evans, 1965, $R$. vesculus Evans, 1965, $R$. subviridis (Kieffer, 1911), R. violaceus Evans, 1965, R. septemlineatus Kieffer, 1906 and $R$. lobatifrons Kieffer, 1906 are examined, the species variation analyzed, new biogeographical data added and had their sting and male genitalia described.

Illustrations of genitalia are presented with dorsal view on the left and ventral view on the right, and those of paramere and cuspis with ventral side on the right. Abbreviations used mostly follow Evans (1964): (LFW) length of forewing; (WH) maximum width of head, including eyes; $(\mathrm{LH})$ length of head, measured from apical margin of clypeus to median point of vertex; (WF) minimum width of frons; (HE) maximum height of eye; (WOT) maximum width of ocellar triangle, including posterior ocelli; (OOL) shortest ocello-ocular line; (VOL) vertex-ocular line, measured in lateral view; (DAO) diameter of anterior ocellus. The nomenclature of the integument follows HARRIS (1979).

1) Departamento de Biologia, Universidade Federal do Espirito Santo. Avenida Marechal Campos 1468, 29040-090 Vitória, Espírito Santo, Brasil.

E-mail: cazevedo@npd.ufes.br 
The material examined in this study was provided by Museum of Comparative Zoology, USA (MCZH, P.D. Perkins); Ohio State University, USA (OSUC, N. Johnson); National Museum of Natural History, USA (USNM, K.V. Krombein); California Academy of Sciences, San Francisco, USA (CASC, W. Pulawsky); Instituto Nacional de Pesquisas da Amazônia, Brazil (INPA, C. Magalhães); Museu Paraense Emílio Goeldi, Brazil (MPEG, A. Harada); Universidade Federal do Acre (UFAC, E.F. Morato); Instituto Brasileiro de Geografia e Estatística, Brasília, Brazil (IBGE, B. Dias); Museu de Biologia Mello-Leitão (MBLM, M. Zortea); Universidade Federal do Espírito Santo, Brazil (UFES, C.O. Azevedo); Museu Nacional do Rio de Janeiro, Brazil (MNRJ, R.Tibana); Fundação Instituto Oswaldo Cruz, Brazil (FIOC, S.J. Oliveira); Universidade Federal de São Carlos, Brazil (DCBU, A.M. Penteado-Dias) and Universidade Federal do Paraná (DZUP, K. Zanol).

\section{Rhabdepyris (Chlorepyris) longifoveatus sp.n.}

Figs 1-7

Description. Male, holotype: length of body $4.25 \mathrm{~mm}$; LFW $2.75 \mathrm{~mm}$.

Color. Head and thorax black with dark green reflections; propodeum and gaster black; palpi castaneous; mandibles black, but rufous at edge of teeth; antennae castaneous, scape darker; tegulae castaneous; coxae black, femora and trochanters dark castaneous, tibiae and tarsi castaneous, hind tibiae darker; forewings subhyaline, with veins and stigma dark castaneous, hindwings hyaline.

Head (Fig. 1). Mandibles with five teeth, the lower larger and more sharpened than the others. Clypeus small, obtusely subangulate slightly rounded off, with a very evident median carina and arched downward in profile, clypeus forming a re-entrance in the region of contact with the frons. First four antennal segments in a ratio of about 16:9:7:10 (Fig. 2), third segment $0.67 \mathrm{X}$ as long as thick, the others longer than thick. Frons polished and brilliant, with punctures small and shallow, much more sparse above, with a small median groove from clypeus. WH $1.18 \mathrm{X}$ LH; WF 0.71 X WH; WF 1.5 X HE; OOL 1.2 X WOT, frontal angle of ocellar triangle obtuse. Vertex slightly convex with lateral angle rounded off, distance from eye tops to vertex crest $0.29 \mathrm{X}$ HE. The posterior ocelli about their own diameter from the vertex crest.

Mesosoma (Figs 3-4). Dorsum of thorax very weakly coriarious; the length of pronotal disc and mesoscutum are the same; notauli very wide posteriorly, separated behind by the same width of one notaulus, slightly arched medially inward and reaching both anterior and posterior margins; parapsidal furrows thin, slightly arched medially inward, not reaching the anterior margin of mesoscutum; scutellar groove deep, arched backward and widened at each end. Propodeal disc (Fig. 4) $1.48 \mathrm{X}$ as wide as long, with three discal carinae, with evident transversal striae among them, the median carina complete and the others converging posteriorly and reaching the median one; posterior part of the disc with short longitudinal striae; posterior angle foveolate; lateral part of disc concave in profile, with a elongate fovea (3.5 X as long thick), occupying a half of disc; lateral carinae are lower than sublateral carinae in profile, space between lateral and sublateral with a longitudinal 


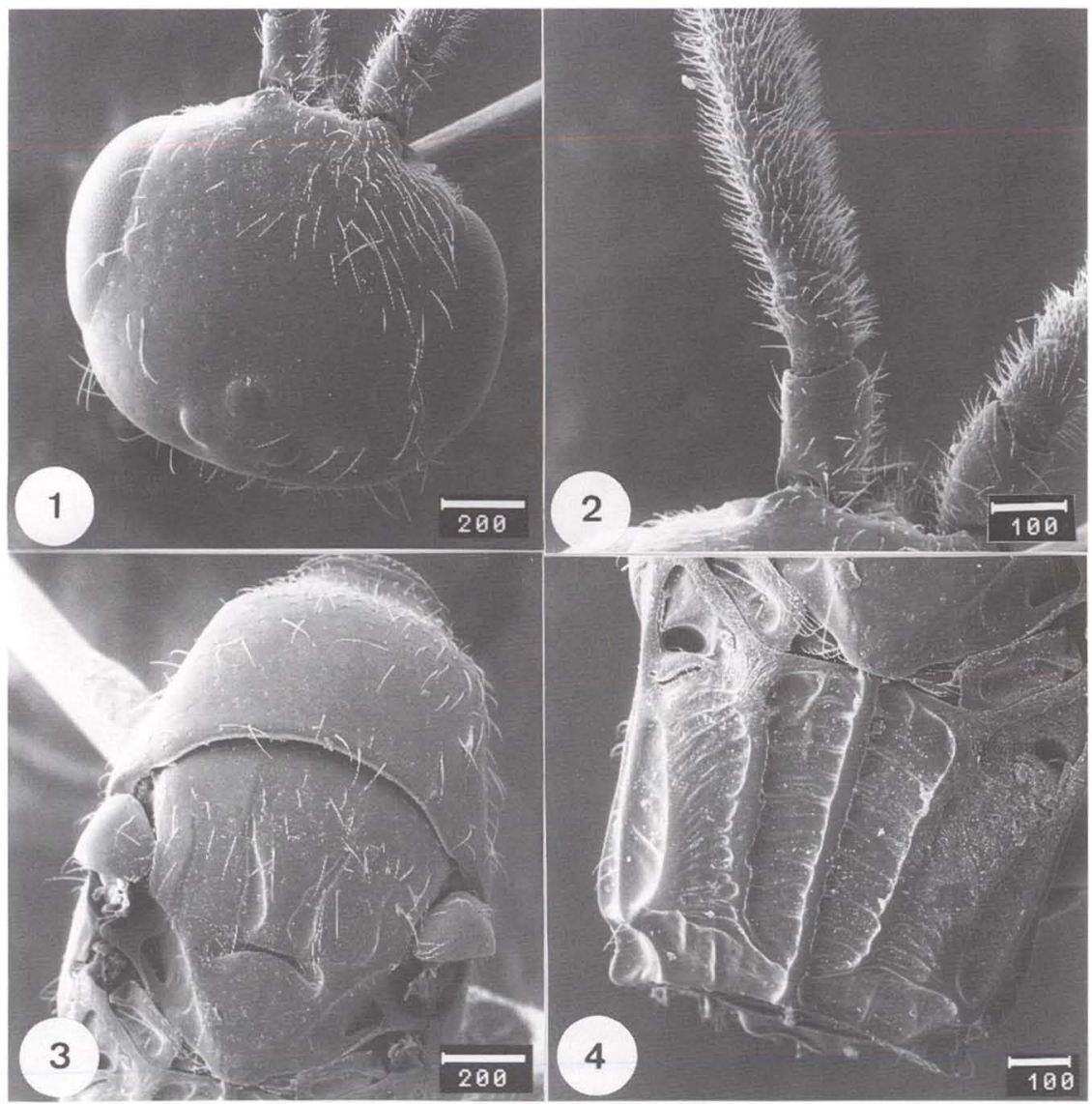

Figs 1-4. Rhabdepyris (C.) longifoveatus sp.n.. (1) Head, dorsal; (2) antenna, dorsal; (3) thorax, dorsal; (4) propodeal disc, dorsal. Scale bars in $\mu \mathrm{m}$ ).

groove; declivity of propodeum with a median carina, superior part coriarious and inferior with perpendicular striae; lateral of propodeum with weak longitudinal striae. Metapleuron with longitudinal striae, being the lower more evident. Pleurosternum slightly coriarious, with a transversal band of the small longitudinal carinae paralleling its anterior margin, and with a subcircular depression near to midcoxa, with a latero-posterior carina reaching the posterior margin and occupying the posterior half of pleurosternum. Mesopleuron polished and brilliant, with a large lower fovea, its upper margin very undefined, upper fovea open posteriorly and upper margin straight. Mid and hindtibiae weakly spinose. Midfemur $1.67 \mathrm{X}$ as long as wide and the forefemur $2.22 \mathrm{X}$. Claws trifid, first tooth rounded off, second truncate and third sharpened.

Gaster with tergites polished and smooth, I and II with a median ring of hairs. Sternites also with hairs in the same place. Transversal section of abdomen circular. Hypopygium with median stalk $0.9 \mathrm{X}$ the length of hypopygium, posterior margin 

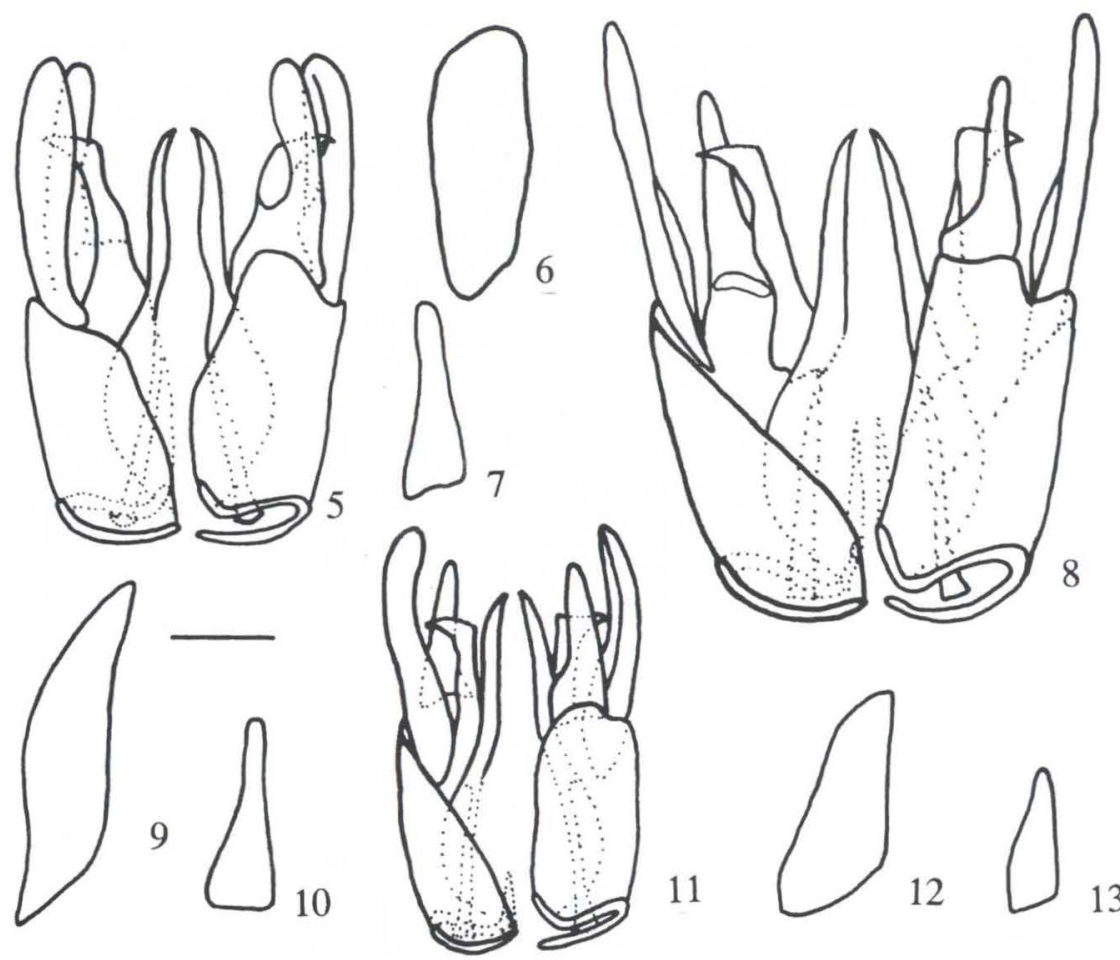

Figs 5-13. (5-7) Rhabdepyris (C.) longifoveatus sp.n.: (5) genitalia, dorsal on left, ventral on right; (6) paramere, lateral, (7) cuspis, lateral, (8-10) R. (C.) vesiculosus sp.n.: (8) Genitalia dorsal on left, ventral on right; (9) paramere, lateral; (10) cuspis, lateral; (11-12) $R$. (C.) virescens: (11) genitalia dorsal on left, ventral on right; (12) paramere, lateral; (13) cuspis, lateral. Scale bar $=115 \mu \mathrm{m}$.

slightly concave. Genitalia (Fig. 5): with paramere (Fig. 6) $0.39 \mathrm{X}$ as wide as long, apex wide, oblique and blunt, not arched inward, dorsal and ventral margins few developed below, so that the paramere is wider above, dorsal margin concave below; volsella with cuspis (Fig. 7) as high as paramere and slightly widened below, digitus much shorter than cuspis; aedeagus bottle-shaped, as high as digitus, base dilated and rounded below, apodema dilated below.

Material examined. Holotype: male; BrazIL, São Paulo: Luiz Antônio, 12.V.1988, L.A. Joaquim leg. (DCBU). Paratypes BRAZIL: 19 males; same data as type, several dates (DCBU); Ibitinga, rubber-tree crop, 124 males, 30.IV.19879.VIII.1989, white or yellow pan trap, no collector given (UFES).

Variations. WH 1.10-1.22 X LH; WF 0.63-0.76 X WH; WF 1.23-1.54 X HE; OOL 0.89-1.4 X WOT; notaulus straight; scutellar groove large and deep, but, in some cases thinner; propodeal disc 1.28-1.56 X as wide as long; transversal striae among discal carinae of propodeal disc as strong longitudinal striae; upper margin of upper fovea of mesopleuron slightly sinuous; lower part of metapleuron with very strong striae, remembering carinae. 
Remarks. This species is similar to $R$. (C.) subviridis, differing by the number of discal carinae in propodeal disc and by the form of superior margin of superior fovea of mesopleuron, straight in $R$. (C.) longifoveatus sp.n. and arched in $R$. (C.) subviridis. Besides, the paramere in $R$. (C.) longifoveatus sp.n. is wide, mainly in the base, while it is evenly thin in $R$. (C.) subviridis.

Etymology. Name refers to the elongate fovea in propodeal disc.

\section{Rhabdepyris (Chlorepyris) vesiculosus sp.n.}

Figs 8-10

Rhabdepyris (Chlorepyris) virescens Evans, 1965: 133 in partim.

Description. Male, holotype: length of body $5.6 \mathrm{~mm}$; LFW $3.5 \mathrm{~mm}$.

Color. Head and thorax shining black, with bluish green reflections, propodeum black, gaster black with apex brown; palpi, mandible and antenna castaneous, scape black; coxae black, femora dark castaneous, forefemur with metallic reflections, trochanters, tibiae and tarsi light castaneous; tegula castaneous, wings subhyaline, veins and stigma castaneous.

Head. Mandibles with five apical teeth, the lower large and the others small in a vertical line. Clypeus small, obtusely angulate, with a conspicuous and high median carina. First four antennal segments in a ratio of about 13:4:4:6, third segment $0.7 \mathrm{X}$ as long as thick, the others longer than thick. Frons very weakly coriarious, nearly polished, brilliant, with punctures small, separated by 3-4 X their diameters. WH 1.11 X LH, WF 0.65 X WH, WF 1.27 X HE, OOL 1.03 X WOT, frontal angle of ocellar triangle obtuse. Vertex straight with rounded corners, distance from the eye tops to vertex crest $0.26 \mathrm{X} \mathrm{HE}$. The posterior ocelli distant from the vertex crest $0.5 \mathrm{X}$ DAO. Gena $0.5 \mathrm{X}$ as high as long.

Mesosoma. Thorax as coriarious as frons, pronotal disc slightly shorter than mesoscutum; notauli wide behind, separated each other $1.5 \mathrm{X}$ their own width, almost reaching both anterior and posterior margins of the mesoscutum. Parapsidal furrows absent in the anterior fourth, reaching posterior margin of the mesoscutum. Scutellar groove deep, arched backward and widened at each end. Propodeal disc $1.55 \mathrm{X}$ as wide as long, with five discal carinae, the median one complete and the others nearly so, space between them with some transversal striae; with lateral and sublateral carinae, space between them with undefined striae, space between discal and sublateral carinae polished, except the short transversal striae near the carinae; posterior corners foveolate; declivity and lateral of propodeum with transversal striae, declivity with median carina. Pleurosternum with a posterior median groove, and a pit near each median coxa, with a posterior lateral carina. Mesopleuron with lower fovea opened on the middle third and upper fovea subcircular and opened downward behind. Mid and hindtibiae weakly spinose. Forefemur $2.07 \mathrm{X}$ as long as thick. Claw trifid, basal lobe rounded, the two apical sharpened and arched.

Gaster. Polished, tergites III-VIII with posterior rings of hairs. Transversal section circular. Gaster slightly shorter than mesosoma. Hypopygium with median stalk $0.75 \mathrm{X}$ the hypopygium, posterior margin narrow and concave. Genitalia (Fig. 8): paramere (Fig. 9) elongate, apex thin and rounded, ventral margin concave in 
the apical half, dorsal margin slightly concave in the basal half and convex apically, so that the paramere is sinuous in lateral view, its transversal section elliptical in the basal half and more dilated inward, base of the paramere developed downward dorsally; volsella with cuspis (Fig. 10) shorter than paramere, gradually thinner to the apex, digitus shorter than cuspis; aedeagus bottle-shaped, as high as digitus, base dilated and rounded below, apodema slightly dilated below.

Description. Female, alotype: length of body $6.49 \mathrm{~mm}$; LFW $3.8 \mathrm{~mm}$.

Color. Head and thorax shining black, with bluish green reflections, propodeum black, gaster black with apex bright ferruginous; palpi, mandible and antenna castaneous; coxae black, fore and hindfemora dark castaneous, forefemur with metallic reflections, midfemur, trochanters, tibiae and tarsi castaneous; tegula castaneous, wings subhyaline, veins and stigma castaneous.

Head. Mandibles with five apical teeth, the lower large and the others small in a inclined line. Clypeus small, obtusely angulate, with a conspicuous and high median carina, forming a re-entrance in region of contact with frons. First four antennal segments in a ratio of about 16:4:3:5.5, third segment $0.54 \mathrm{X}$ as long as thick, the others longer than thick. Frons weakly coriarious, brilliant, with punctures small, separated by 1-3 X their diameters, posteriorly more sparse. WH $1.0 \mathrm{X} \mathrm{LH}$, WF $0.68 \mathrm{X} \mathrm{WH}$, WF $1.27 \mathrm{X} \mathrm{HE}$, OOL $1.33 \mathrm{X}$ WOT, frons angle of ocellar triangle right. Vertex straight with rounded corners, distance from the eye tops to vertex crest $0.22 \mathrm{X}$ HE. The posterior ocelli distant from the vertex crest $0.86 \mathrm{X}$ DAO. Gena $0.5 \mathrm{X}$ as high as long.

Mesosoma. Thorax as coriarious as frons, pronotal disc $1.2 \mathrm{X}$ as long as mesoscutum; notauli wider and convergent behind, much separated each other, not reaching the margins of the mesoscutum. Parapsidal furrows absent in the anterior fourth, reaching posterior margin of the mesoscutum. Scutellar groove deep, arched backward and widened at each end. Propodeal disc $1.0 \mathrm{X}$ as wide as long, with five discal carinae, the median one complete and the others nearly so, space between them with a longitudinal striae; with lateral and sublateral carinae, space between them with undefined striae, space between discal and sublateral carinae polished; posterior corners foveolate; declivity with median carina and transversal striae below; lateral of propodeum coriarious. Pleurosternum with two posterior median pits, and a pit near each median coxa, with a posterior lateral groove. Mesopleuron with lower fovea opened on the middle third and upper fovea ovoid and closed. Midtibia spinose, midspur $0.37 \mathrm{X}$ as long as midtibia. Forefemur $1.97 \mathrm{X}$ as long as thick. Claw trifid, basal lobe rounded, the two apical sharpened and arched.

Gaster. Polished, tergites III-VIII with posterior rings of hairs. Transversal section circular. Gaster shorter than mesosoma. Sting apparatus $1.13 \mathrm{~mm}$, with 8 small dorsal teeth, the two apical rounded and the two basal much separated.

Material examined. Holotype, male, PANAMA, Canal Zone: Barro Colorado Island, 18.VII.1956, C.W. \& M.E. Rettenmeyer leg., 2127 (KSUC, paratype of $R$. virescens). ECUADOR: Ontoga (8 km SE Tena), 1 male paratype, V.1963, L. Peña leg. (MCZH, paratype of $R$. virescens). PANAMA: Porto Bello, female alotype, 21.II.1911, E.A. Schwarz leg. (USNM, paratype of $R$. virescens). 
Remarks. This species represents those $R$. virescens specimens from Central America and northwestern of South America. They are similar to each other, but the paramere of this species is thin apically and the transversal section of the base is expanded as a vesicle, reason for its name. This expanded paramere is unique in Bethylidae, it is usually laminar.

\section{Rhabdepyris (Chlorepyris) virescens Evans, 1965}

Figs 11-13

This species is now known from Brazil (Santa Catarina) and it is recorded for the first time from Distrito Federal, São Paulo and Paraná. Male genitalia (Fig. 11): paramere (Fig. 12) with rounded apex, hardly arched inward, ventral and dorsal margin nearly straight, being the dorsal one convergent below, so that the paramere is wide basally, base developed inward dorsally; volsella with cuspis (Fig. 13) slightly shorter than paramere, widened evenly to the base; digitus shorter than cuspis; aedeagus bottle-shaped, as high as digitus, apodema slightly dilated below. Sting apparatus $1.55 \mathrm{~mm}$, sting with 9 small dorsal teeth, the two basal ones much separated.

Material examined. BRAZIL, Santa Catarina: Seara (Nova Teutônia), 1 male, II.1964, F. Plaumann leg. (MCZH, paratype). New material: BRAZIL, Distrito Federal: Brasília (Ecological Reserve of IBGE, 155' $\left.58^{\prime \prime} \mathrm{S}, 47^{\circ} 51^{\prime} 02^{\prime \prime} \mathrm{W}\right), 22$ males and 28 females, 22.XII.1979-1.III.1984, window trap, J. Dalmácio leg. (IBGE); São Paulo: Luiz Antônio (Jataí Ecological Station, forest), 2 males and 1 female, 16-30.X.1986, sweeping (males) or Malaise trap (female), L.A. Joaquim leg. (DCBU); São Carlos (Canchim Farm, forest), 3 males, 15.IX-8.XII.1988, Malaise trap, L.A. Joaquim leg. (DCBU); Ibitinga, rubber-tree crop, 1 female, 11.I.1988, yellow pan trap (UFES); Paraná: Fênix (Reserve ITCF Station), 1 male, 2.II.1987, Malaise trap, Profaupar survey (DZUP); Colombo, (Embrapa, Br 476, Km 20), 1 female, 31.VIII.1987, Malaise trap, Profaupar survey (DZUP); Guarapuava, 2 females, 22.VI-31.VIII.1987, Malaise trap, Profaupar survey (DZUP).

\section{Rhabdepyris (Chlorepyris) vesculus Evans, 1965}

Figs 14-16

This species was known only from the type series from Santa Catarina (Brazil) and now it is recorded to the first time from Espírito Santo, São Paulo and Paraná. It is typically black, some black specimens with weak dull olive-green reflections were analyzed. In this series, scape distinctly darker than the other antennal segments; WH 1.07-1.16 X LH; WF 0.67-0.73 X WH; WF 0.6-0.76 X HE; WOT 1.0-1.05 X OOL; lower fovea of the mesopleuron polished or coriarious. Hypopygium with median stalk $0.5 \mathrm{X}$ as long as its length, posterior margin angulate and invaginated. Male genitalia (Fig. 14): paramere (Fig. 15) wide, 0.55 $\mathrm{X}$ as wide as long, apex wide and not arched inward, oblique and blunt, dorsal margin very slightly concave and slightly divergent below, ventral margin straight and parallel, base of paramere developed inward in the dorsal side; volsella with cuspis 
(Fig. 16) slightly shorter than the paramere, with a ventral apical projection with the same size as it, digitus slightly shorter than cuspis; aedeagus bottle-shaped, as high as digitus, base angulate below, apodema much dilated below.

Material examined. BRAzIL, Santa Catarina: Seara (Nova Teutônia), 1 male, I.1963, F. Plaumann leg., paratype (USNM). New material: BRAZIL, Espírito Santo: Cariacica (Duas Bocas Biological Reserve, forest), 10 males, 29.IX.199626.VIII.1997, sweeping, C.O. Azevedo or H.S. Sá leg. (UFES); São Paulo: São Carlos (Canchim Farm, cerrado), 2 males, 10.XI.1989, pitfall and 11.X.1989, Malaise trap; N.W. Perioto leg. (UFES); Paraná: Jundiaí do Sul (Monte Verde Farm), 4 males, 22.IX.1986-12.I.1987, Profaupar survey, Malaise trap (DZUP); Ponta Grossa (Vila Velha, Reserve IAPAR, BR 376), 1 male, 1.II.1988, Profaupar survey, Malaise trap (DZUP).

\section{Rhabdepyris (Chlorepyris) subviridis (Kieffer, 1911)}

Figs 17-19

This species is known to Mexico and Central America. Posterior margin of hypopygium slightly convex. Genitalia (Fig. 17): paramere (Fig. 18) evenly thin, $0.28 \mathrm{X}$ as wide as long, apex rounded, dorsal and ventral margins parallel, the ventral slightly convex base not developed; volsella with cuspis (Fig. 19) long and thin, slightly shorter than the paramere, its base only slightly widened; digitus much shorter than cuspis; aedeagus bottle-shaped, as high as digitus, apodema dilated below. Sting apparatus $2.06 \mathrm{~mm}$, sting without teeth.

Material examined. Costa RicA: Turrialba (cr 49 fis), 1 male (USNM). PANAMA, Canal Zone: Pacora, 1 female, 14.V.1955 (USNM).

\section{Rhabdepyris (Chlorepyris) violaceus Evans, 1965}

Figs 20-22

This species is known only from Mato Grosso and Santa Catarina State and now a female from São Paulo and male from Espírito Santo Paraná are recorded. In the female, reflections predominantly green, with blue-violet reflections under inclined light; green head and thorax contrasts to the violet propodeum; ventral side of all coxae and outer side of forefemora with metallic reflections and hindfemur ferruginous. The color pattern of the legs remembers those of $R$. tricolor Evans, 1965. WH 1.24 X LH; ocellar triangle more compact, OOL 1.42 X WOT, propodeal disc $1.43 \mathrm{X}$ as wide as long; apparatus sting $2.1 \mathrm{~mm}$, sting without teeth. In male from Paraná, WH 1.12 X LH, WF 0.7 X WH, WF 1.36 X HE, OOL 1.08 X WOT, parapsidal furrows incomplete anteriorly, propodeal disc $1.35 \mathrm{X}$ as wide as long, with transversal ridges between the 3 discal carinae as strong as carina. Male genitalia (Fig. 20): paramere (Fig. 21) wide, with apex wide, oblique and blunt, both dorsal and ventral margins diverging below, so that the paramere is wider below, dorsal margin developed downward; volsella with cuspis (Fig. 22) slightly shorter than paramere, elongate with apex slightly wider, inner margin concave; digitus shorter than cuspis; aedeagus bottle-shaped, base subangulate below, apodema 
much dilated below. Male from Espírito Santo predominantly blue-green as $R$. (C.) fulgens (Brues, 1907), but notaulus very wide behind.

New material examined. BRAzIL, Espírito Santo: Cariacica (Duas Bocas Biological Reserve, forest), 1 male, 17.XII.1996, sweeping, C.O. Azevedo leg. (UFES); Paraná: Colombo (Embrapa, Br 476, Km 20), 1 male, 7.XII.1987, Malaise trap (DZUP), Profaupar survey; São Paulo: São Carlos (Canchim Farm, forest), 1 female 4.VII.1988, Malaise trap, L.A. Joaquim leg. (DCBU).
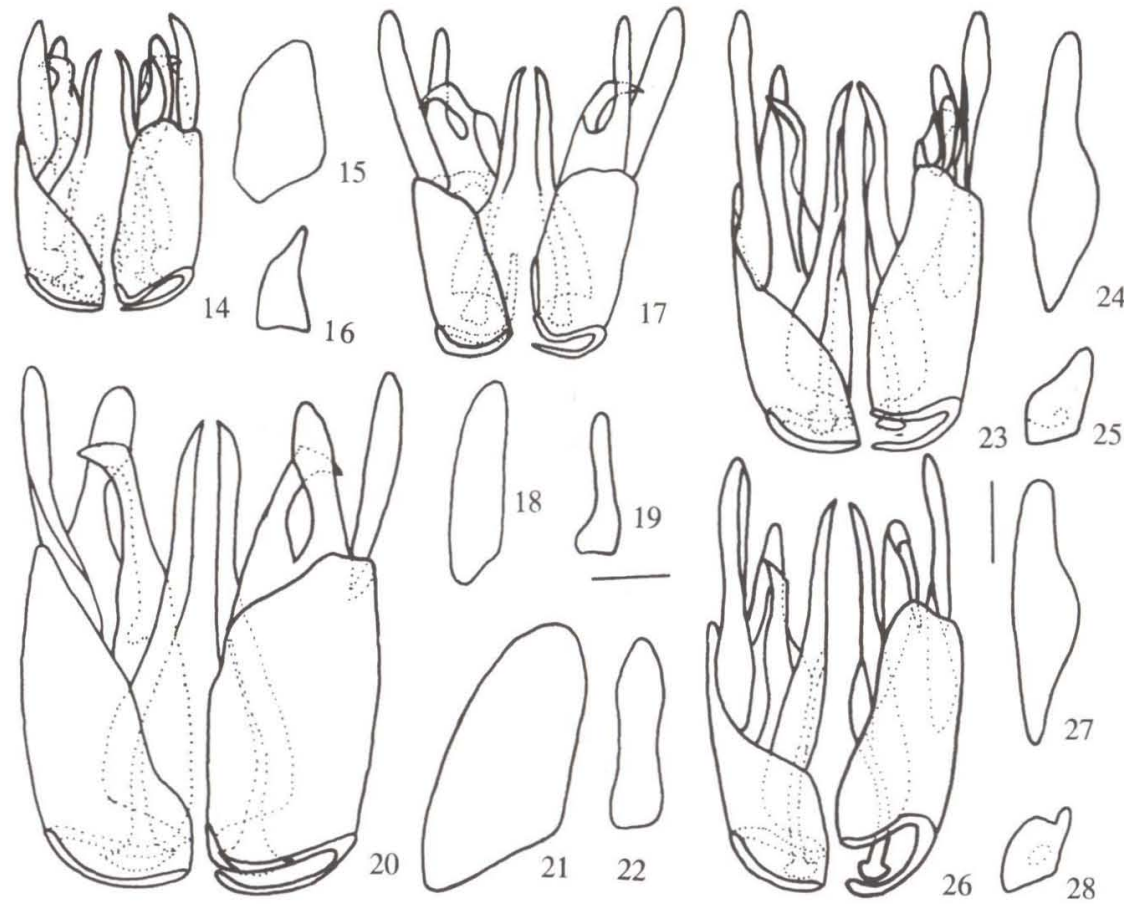

Figs 14-28. (14-16) Rhabdepyris (C.) vesculus: (14) genitalia dorsal on left, ventral on right; (15) paramere, lateral; (16) cuspis, lateral; (17-19) R. (C.) subviridis: (17) genitalia dorsal on left, ventral on right; (18) paramere, lateral; (19) cuspis, lateral; (20-22) $R$. (C.) violaceus: (20) genitalia dorsal on left, ventral on right; (21) paramere, lateral; (22) cuspis, lateral. (23-25) Rhabdepyris (C.) septemlineatus: (23) genitalia dorsal on left, ventral on right; (24) paramere, lateral; (25) cuspis, lateral; (26-28) R. (C.) lobatifrons: (26) genitalia dorsal on left, ventral on right; (27) paramere, lateral; (28) cuspis, lateral. Scale bar $=115 \mu \mathrm{m}$.

\section{Rhabdepyris (Chlorepyris) septemlineatus Kieffer, 1906}

Figs 23-25

This species was known only from the type series (2 specimens) from Panama and Nicaragua and Brazil, Santa Catarina. Now, it is recorded for the first time from Brazil, Amazonas, Espírito Santo, São Paulo, Paraná). In this series, length of body $4.25-6.00 \mathrm{~mm}$, WH 0.88-1.02 X LH; WF 0.45-0.54 X WH; WF 
0.87-1.11 X HE; OOL 1.27-1.6 X WOT; propodeal disc 1.5-1.83 X as wide as long; notauli, parapsidal furrows, scutellar groove, clypeus, mandibles and spinose tibiae similar to the type, discal carinae of propodeal disc different because the outer pair of ones occupies the anterior $0.5-0.88 \mathrm{X}$ of the disc and the others complete and slightly divergent posteriorly. Genitalia (Fig. 23): paramere (Fig. 24) thin and elongate, $2 \mathrm{X}$ as long as base of genitalia in dorsal view, apex thin and rounded, base dilated dorsal and ventrally, and developed downward dorsally; volsella with cuspis (Fig. 25) wide basally and narrowing evenly apically, cuspis rather shorter than paramere; digitus shorter than cuspis; aedeagus bottle-shaped, base rounded laterally, slightly shorter than cuspis, apodema much dilated below. In specimens from Brazil, paramere less wide basally and wider apically, cuspis with apex blunt and shorter, as high as aedeagus. Specimen from Espírito Santo, apex of the cuspis with very thin groove.

Material examined. Panama, Canal Zone: Barro Colorado, Imale, 11.II.1955, C. Rettenmeyer leg. (KSUC, paratype). New material: BRAZIL, Amazonas: Manaus (Ducke Reserve), 1 male, 25-29.VII.1992, glue trap, 2m, Vidal \& Vidal leg. (INPA); Espírito Santo: Santa Teresa, pt 1, 1 male, 4.IX.1989, 13:25h; A.P. Aguiar leg. (MBLM), Cariacica (Duas Bocas Biological Reserve, forest), 42 males, 10.X.1996-1.VIII.1997, sweeping, C.O. Azevedo, H.S. Sá or E.H. Freitas leg. (UFES); São Paulo: Ibitinga, rubber-tree crop, 2 males, 2.XI.1988-9.VIII.1989, Möricke (UFES); Bauru (Ecological Station or Terry Park), 3 males, 24.IV.199120.VII.1993, S.S. Ruiz leg. (UFES); Luiz Antônio (Jataí Ecological Station), 5 males, 26.III.1987-18.IV.1989, sweeping; L.A. Joaquim leg. (DCBU); São Carlos (Canchim Farm, cerrado), 2 males, sweeping or Malaise trap, L.A. Joaquim leg. (DCBU); São Carlos (Ecological Park), 1 male, 4.I.1987, F. Passos leg. (DCBU); Paraná: Antonina (Sapitanduva Reserv), 1 male, 15.VI.1987, Malaise trap, Profaupar survey (DZUP); Fênix (ITCF State Reserve), 5 males, 1.IX.1986-20.IV.1987, Malaise trap, Profaupar survey (DZUP); Jundiaí do Sul (Monte Verde Farm), 18 males, 11.VIII.1986-19.I.1987, Malaise trap, Profaupar survey (DZUP); Telêmaco Borba (Samuel Klabin Farm), 3 males, 11.VIII-1.IX.1986, Malaise trap, Profaupar survey (DZUP); Ponta Grossa (Vila Velha), 1 male, 8.II.1988, Malaise trap, Profaupar survey (DZUP).

\section{Rhabdepyris (Chlorepyris) lobatifrons Kieffer, 1906}

Figs 26-28

This species was known only from the type from Brazil (Pará) and now it is recorded from Brazil (Acre). In this series, lateral discal carinae of the propodeum disc straight, propodeal disc 1.67-1.9 X as wide as long; hypopygium with median stalk $0.63 \mathrm{X}$ the length of hypopygium, anterior margin much developed laterally, as high as stalk, posterior margin slightly straight. Genitalia (Fig. 26): paramere (Fig. 27) somewhat thin and elongate, $2 \mathrm{X}$ as long as the base of the genitalia, apex thin and rounded, base dilated ventrally, and developed downward dorsally, apical half $0.5 \mathrm{X}$ as wide as basal half; volsella with cuspis (Fig. 28) wide, apex oblique and deeply excavated at the middle, much shorter than paramere, digitus slightly 
shorter than cuspis; aedeagus bottle-shaped, base rounded laterally, slightly higher than cuspis, apodema much dilated below.

Material examined. BrazIL, Pará: Backer leg., 6700 (CASC, holotype, male). New material: BraziL, Acre: Serra do Divisor National Park, 3 males, 8.XI.1996-19.III.1997, Malaise trap, E.F. Morato leg. (UFES, UFAC).

Remarks. This species is similar to $R$. (C.) septemlineatus. The main differences between them are in genitalia. In $R$. (C.) lobatifrons cuspis excavated apically, aedeagus higher than cuspis, apical half of the paramere not so thin.

ACKNOWLEDGMENTS. To E.R. Bortolini (UFES) for the loan of camera lucida and to curators cited in the text for the loan of the material studied here.

\section{REFERENCES}

AZEVEDO, C.O. 1992a. On Rhabdepyris Kieffer (Hymenoptera, Bethylidae) in the area of São Carlos: I. Subgenus Rhabdepyris (Rhabdepyris). Revta bras. Ent. 36 (1): 241-4.

-1992b. Sobre os Rhabdepyris Kieffer (Hymenoptera, Bethylidae) coletados em Piçarras, SC, Brasil. Revta bras. Ent. 36 (2): 251-4.

. 1993. On Rhabdepyris Kieffer (Hymenoptera, Bethylidae) in the area of São Carlos, State of São Paulo, Brazil: II. Subgenus Trichotepyris. Revta bras. Ent. 37 (2): 305-8.

Evans, H.E. 1964. A Synopsis of the (Hymenoptera: Aculeata). Bull. Mus. Comp. Zool. 132 (1): 1-222.

1965. A Revision of the Genus Rhabdepyris in the Americas (Hymenoptera: Bethylidae). Bull. Mus. Comp. Zool. 133 (3): 68-151.

HARRIS, R.A. 1979. A glossary of surface sculpturing. Occ. Pap. Ent. 28: 1-31.

Recebido em 19.III.1998; aceito em 27.VIII.1999. 